\title{
Simultaneous bilateral spontaneous pneumothorax in an adult patient with cystic fibrosis*
}

\author{
Pneumotórax espontâneo simultâneo bilateral \\ em um paciente adulto com fibrose cística \\ Kamlesh Mohan, Martin James Ledson, \\ Martin John Walshaw, Edson Marchiori
}

\begin{abstract}
Pneumothorax is a common complication in cystic fibrosis and is associated with worsening of lung function. However, bilateral simultaneous pneumothorax in cystic fibrosis is a rare condition. We describe the case of a 17-year-old female with cystic fibrosis who presented with spontaneous pneumothorax. Clinically, she presented right-sided chest pain and progressive breathlessness. The pneumothorax failed to resolve after the initial treatment (chest drainage). However, the patient was later successfully treated with additional chest drainage and talc pleurodesis. We also discuss the etiology and management of pneumothorax in patients with cystic fibrosis, since pneumothorax is associated with increased morbidity and mortality among such patients.
\end{abstract}

Keywords: Cystic fibrosis/physiopathology; Pneumothorax; Pleurodesis.

\section{Resumo}

0 pneumotórax é uma complicação comum na fibrose cística e está associado com a piora da função pulmonar. Entretanto, o pneumotórax simultâneo bilateral na fibrose cística é um achado raro. Nesse artigo é descrito o caso de uma paciente de 17 anos com fibrose cística que cursou com pneumotórax espontâneo simultâneo bilateral. Clinicamente ela apresentou dor torácica à direita e dificuldade respiratória progressiva. Embora o pneumotórax não tenha respondido bem ao tratamento inicial (drenagem torácica), ela foi posteriormente tratada com drenagem e pleurodese com talco, com sucesso. São discutidos também a etiologia e a conduta nesta condição, que está associada com o aumento da morbidade e mortalidade.

Descritores: Fibrose cística/fisiopatologia; Pneumotórax; Pleurodese.

\section{Introduction}

Cystic fibrosis is characterized by progressive lung inflammation and deterioration of pulmonary function. Pneumothorax is a common complication in cystic fibrosis patients, who can present increased morbidity caused by exacerbation of the respiratory manifestations of cystic fibrosis, which can lead to respiratory failure and death. The aim of cystic fibrosis treatment is the safe and effective resolution of pneumothorax with prevention of recurrence. However, lack of response to initial treatment is common, as is recurrence, and interventions to prevent recurrence are no longer considered a contraindication to future lung transplantation. Although chemical pleurodesis and surgery have a high success rate in the prevention of recurrent pneumothorax in the non-cystic fibrosis population, there is little evidence in the literature regarding their efficacy in cystic fibrosis patients. Here, we describe a rare presentation of spontaneous pneumothorax in an adult patient with cystic fibrosis. In addition, we discuss the etiology and management of pneumothorax in cystic fibrosis patients, the prevalence of which is likely to increase, since the expected life span of these patients continues to increase.

\footnotetext{
* Study carried out in the Adult Cystic Fibrosis Unit of the Cardiothoracic Centre NHS Trust, Liverpool, UK.

Correspondence to: Martin J. Walshaw. The Adult Cystic Fibrosis Unit. The Cardiothoracic Centre NHS Trust. Thomas Drive. Liverpool L143PE. United Kingdom.

Tel 44151 228-1616. Fax 44151 288-2647. E-mail: mwalshaw@doctors.org.uk

Financial support: None.

Submitted: 25 March 2008. Accepted, after review, 26 May 2008.

**A versão completa em português deste artigo está disponivel em www.jornaldepneumologia.com.br
} 


\section{Case report}

A 17-year-old female with cystic fibrosis (cystic fibrosis transmembrane conductance regulator gene mutation dF508 homozygous) presented with right-sided chest pain and increasing breathlessness. She had a baseline FEV ${ }_{1}$ of $1.4 \mathrm{~L}$ ( $46 \%$ of predicted) and had been chronically infected with the Liverpool epidemic strain (the most common transmissible strain in the UK) of Pseudomonas aeruginosa for many years, requiring up to six courses of intravenous antibiotics per year for pulmonary exacerbations. She did not smoke and had experienced no previous episodes of pneumothorax. Examination showed her to be dyspneic, with a peripheral oxygen saturation of 95\% (in room air); chest auscultation revealed the usual diffuse coarse crackles. Her FEV fell to $0.87 \mathrm{~L}$ (27\% of predicted), and a chest X-ray revealed bilateral pneumothorax: 20\% on the right and a small $(1-\mathrm{cm})$ apical rim on the left (Figure 1).

The right pneumothorax was treated with a 20-gauge Seldinger-type intercostal chest drain, whereas the left pneumothorax was only observed. She was also treated with antibiotics (meropenem, $1 \mathrm{~g}$ tid; and colistin, 2 million units tid), bronchodilators and respiratory therapy. The left pneumothorax resolved without treatment, and the right pneumothorax resolved within 3 days after chest drain insertion. However 2 days later, the right-sided pneumothorax recurred, requiring further chest drainage (for 10 days). Due to her poor general status, she was treated with chemical pleurodesis using $4 \mathrm{~g}$ of talc slurry introduced through the chest tube. A follow-up chest X-ray taken 30 days after the initial evaluation showed no recurrence (Figure 2).

\section{Discussion}

Pneumothorax is a common complication in cystic fibrosis, occurring in up to $20 \%$ of adult patients. ${ }^{(1)}$ However, simultaneous bilateral spontaneous pneumothorax in cystic fibrosis is rare, ${ }^{(2)}$ the most recent report describing its occurrence after a rapid deceleration trauma following a bungee jump. ${ }^{(3)}$ There have also been reports of pneumothorax occurring in patients after the performance of airway clearance techniques or noninvasive ventilation. ${ }^{(4)}$ However, in our patient, there was no history suggestive of a precipitating cause. The natural history of cystic

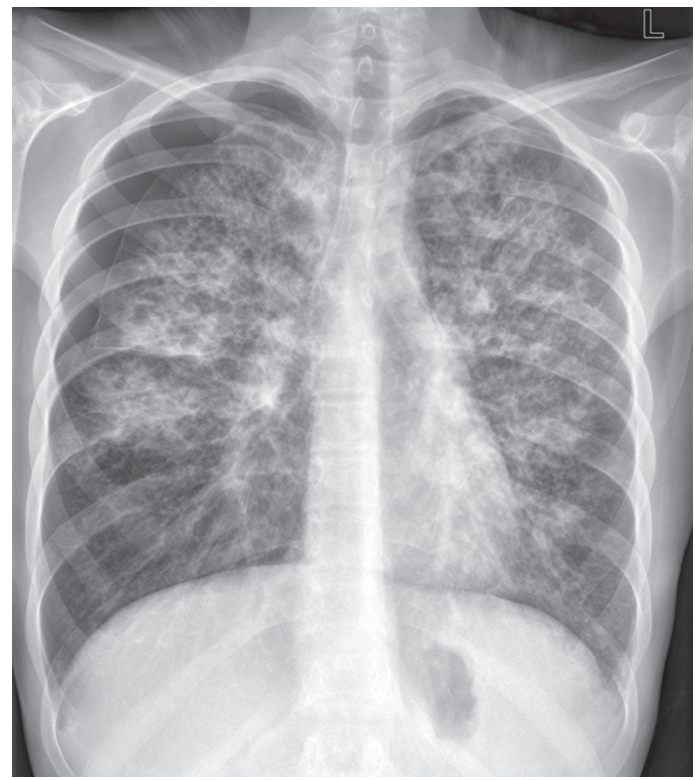

Figure 1 - Chest X-ray showing bilateral pneumothorax and bilateral interstitial infiltration caused by cystic fibrosis.

fibrosis is characterized by progressive inflammation, leading to destruction of the parenchymal architecture and the formation of apical subpleural blebs. ${ }^{(5)}$ Pneumothorax is thought to result from rupture of these subpleural blebs, as has been reported in $84 \%$ of patients undergoing surgical pleurodesis. ${ }^{(6)}$ In addition, alveolar hyperinflation caused by airflow obstruction and air trapping can result in alveolar rupture into the pleural space. ${ }^{(5)}$ Furthermore, recent data from the US Cystic Fibrosis Foundation patient

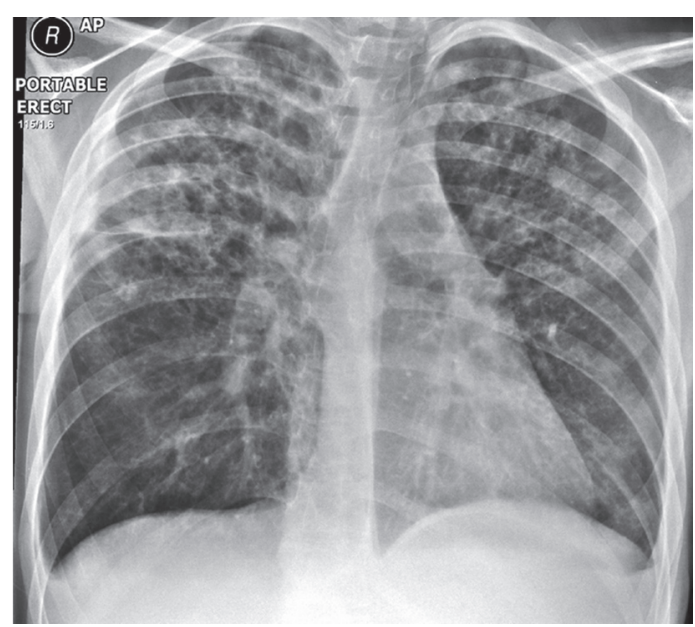

Figure $\mathbf{2}$ - Chest X-ray taken 30 days after the initial evaluation, showing complete resolution of the bilateral pneumothorax. 
registry indicate that, among other factors, advancing age, chronic $P$. aeruginosa infection and severe airflow obstruction are associated with increased risk of pneumothorax..$^{(7)}$ It is likely that the combination of the above factors was responsible for the bilateral presentation in our patient.

Pneumothorax is associated with shortand long-term morbidity and mortality. In an acute presentation, it can result in restriction of chest wall movement, retention of secretions, difficulty in performing adequate respiratory therapy, exacerbation of infection, respiratory failure and death. It is also an independent prognostic factor in cystic fibrosis, with 50\% mortality at 4 years following the first episode of pneumothorax..$^{(7)}$ The management of pneumothorax in cystic fibrosis is largely based on evidence obtained from the non-cystic fibrosis population, and there have been no randomized controlled trials or studies addressing treatment options in cystic fibrosis patients. Lack of response to initial treatment is common, as is recurrence, with recurrence rates of up to $78 \%$ on the ipsilateral and $46 \%$ on the contralateral side. ${ }^{(5)}$ In our patient, chemical pleurodesis was chosen over surgery due to her poor general status and the severity of the lung disease. Talc slurry has been used successfully in the prevention of pneumothorax in non-cystic fibrosis and cystic fibrosis patients. ${ }^{(5,8)}$ A recent study concluded that pleurodesis is not a contraindication for future lung transplantation in cystic fibrosis patients. ${ }^{(9)}$ Further study addressing pneumot- horax in cystic fibrosis (including treatment options such as the timing and best modality of pleurodesis) is needed, since this condition will take on added clinical importance as the survival of these patients continues to improve.

\section{References}

1. Schidlow DV, Taussig LM, Knowles MR. Cystic Fibrosis Foundation consensus conference report on pulmonary complications of cystic fibrosis. Pediatr Pulmonol. 1993;15(3):187-98.

2. Graf-Deuel E, Knoblauch A. Simultaneous bilateral spontaneous pneumothorax. Chest. 1994;105(4):1142-6.

3. Murphy D, O'Mahony M, Logan P, Costello R, McElvaney N. Bilateral pneumothoraces following a bungee jump in a patient with cystic fibrosis. Respiration. 2006;73(1):113.

4. Haworth CS, Dodd ME, Atkins M, Woodcock AA, Webb AK. Pneumothorax in adults with cystic fibrosis dependent on nasal intermittent positive pressure ventilation (NIPPV): a management dilemma. Thorax. 2000;55(7):620-2.

5. Flume PA. Pneumothorax in cystic fibrosis. Chest. 2003;123(1):217-21.

6. Rich RH, Warwick WJ, Leonard AS. Open thoracotomy and pleural abrasion in the treatment of spontaneous pneumothorax in cystic fibrosis. J Pediatr Surg. 1978;13(3):237-42.

7. Flume PA, Strange C, Ye X, Ebeling M, Hulsey T, Clark LL. Pneumothorax in cystic fibrosis. Chest. 2005;128(2):720-8.

8. Henry M, Arnold T, Harvey J; Pleural Diseases Group, Standards of Care Committee, British Thoracic Society. BTS guidelines for the management of spontaneous pneumothorax. Thorax. 2003;58 Suppl 2:ii39-52.

9. Curtis HJ, Bourke SJ, Dark JH, Corris PA. Lung transplantation outcome in cystic fibrosis patients with previous pneumothorax. J Heart Lung Transplant. 2005;24(7):865-9.

\section{About the authors}

\section{Kamlesh Mohan}

Specialist Registrar. The Adult Cystic Fibrosis Unit of the Cardiothoracic Centre, Liverpool, UK.

\section{Martin James Ledson}

Consultant Respiratory Physician. The Adult Cystic Fibrosis Unit of the Cardiothoracic Centre, Liverpool, UK.

\section{Martin John Walshaw}

Consultant Respiratory Physician. The Adult Cystic Fibrosis Unit of the Cardiothoracic Centre, Liverpool, UK.

\section{Edson Marchiori}

Full Professor. Radiology Department. Universidade Federal Fluminense - UFF, Fluminense Federal University - Niterói, Brazil. 